\title{
PENGARUH MODEL PEMBELAJARAN PROBLEM BASED LEARNING UNTUKMENINGKATKAN HASIL BELAJAR SISWA PADA MATERI POKOK FLUIDA STATIS DI KELAS XI SMA NEGERI 9 MEDANT.A. 2013/2014
}

\author{
Rudi Hamonangan Sirait dan Motlan \\ Jurusan Fisika FMIPA Universitas Negeri Medan \\ prudisirait@yahoo.com
}

\begin{abstract}
ABSTRAK
Penelitian ini bertujuanuntuk mengetahui pengaruh model pembelajaran Problem Based Learning untuk meningkatkan hasil belajar siswa pada materi pokok Fluida Statis di kelas XI SMA Negeri 9 Medan T.A. 2013/2014.Jenis penelitian ini adalahquasi eksperimen dengan design penelitian Two Group Pretest-Postest Design. Populasi dalam penelitian ini adalah seluruh siswa kelas XISemester II SMA Negeri 9 Medan yang terdiri dari 4 kelas berjumlah 140 siswa. Sampel penelitian diambil 2 kelas yang ditentukan dengan teknik cluster random sampling, yaitu kelas XI IPA1 yang berjumlah 32 orang sebagai kelas eksperimendan kelas XI IPA 3 yang berjumlah 39 orang sebagai kelas kontrol. Instrumen yang digunakan dalam penelitian ini ada 2, yaitu tes hasil belajar dalam bentuk pilihan berganda sebanyak 16 soal yang telah divalidasikan dan lembar observasi aktifitas belajar siswa yang dilakukan oleh dua observer. Uji Hipotesis menggunakan uji t satu pihak. Dari data penelitian diperoleh nilai rata-rata pretes kelas eksperimen adalah 42,97 dengan standar deviasi 11.08 dan kelas kontrol adalah 42,15 dengan standar deviasi 11.89. Pada uji normalitas kelas eksperimen untuk pretes diperoleh $\mathrm{L}_{\text {hitung }}<\mathrm{L}_{\text {tabel }}=0.1393$ $<0.1566$, sedangkan kelas kontrol $\mathrm{L}_{\text {hitung }}<\mathrm{L}_{\text {tabel }}=0.1150<0.1419$ maka data kedua kelas berdistribusi normal. Pada uji homogenitas data pretes untuk kedua sampel diperoleh $\mathrm{F}_{\text {hitung }}<\mathrm{F}_{\text {tabel }}=1.15<1.76$ maka kedua sampel berasal dari kelompok yang homogen. Hasil penelitian menunjukkan aktivitas siswa meningkat dari pertemuan pertama, kedua dan ketiga. Rata-rata aktivitas pertemuan pertama adalah 36.63 , pertemuan kedua 57.12, dan pertemuan ketiga 63.02. Setelah diberikan perlakuan yang berbeda, kelas eksperimen dengan model pembelajaran Problem Based Learning dan kelas kontrol dengan pembelajaran konvensional, diperoleh nilai postes dengan hasil rata-rata kelas eksperimen 81,06 dan standar deviasi 8.32 dan kelas kontrol 73,24 dan standar deviasi 10.72. Hasil uji t satu pihak postes diperoleh $t_{\text {hitung }}>t_{\text {tabel }}=3.35>1.66$ maka $\mathrm{H}_{\mathrm{a}}$ diterima, dengan demikian diperoleh ada pengaruh terhadap hasil belajar siswa menggunakan model pembelajaran Problem Based Learning untuk meningkatkan hasil belajar siswa pada Materi Pokok Fluida Statis di Kelas XI Semester II SMA Negeri 9 Medan Tahun Pelajaran 2013/2014.
\end{abstract}

Kata kunci : Model Pembelajaran Problem Based Learning, Hasil Belajar, Aktivitas 


\section{PENDAHULUAN}

\section{Bidang}

pendidikan

memegang peranan yang sangat strategis dalam keberhasilan suatu negara. "Pendidikan adalah suatu proses dalam rangka mempengaruhi siswa agar dapat menyesuaikan diri sebaik mungkin terhadap lingkungannya, dengan demikian akan menimbulkan perubahan dalam dirinya yang memungkinkan untuk berfungsi dalam kehidupan masyarakat." (Syah, 2008:10).

Ilmu Pengetahuan Alam (IPA) adalah salah satu mata pelajaran yang dipelajari dalam pendidikan formal, dan juga termasuk ke dalam mata pelajaran yang di Ujian Nasional-kan untuk tingkat Sekolah Menengah Pertama (SMP) dan Sekolah Menengah Atas (SMA). Salah satu bagian dari IPA adalah mata pelajaran Fisika. Fisika merupakan salah satu cabang ilmu pengetahuan alam yang mempelajari fenomena dan gejala alam secara empiris, logis, sistematis, dan rasional yang melibatkan proses dan sikap ilmiah. Namun, kenyataannya fisika sering dipandang sebagai suatu ilmu yang abstrak oleh siswa dengan teori dan soal-soal yang sulit.

Berdasarkan pengalaman penulis saat melakukan Program Pengalaman Lapangan Terpadu (PPLT), bahwa dalam kegiatan belajar mengajar (KBM) siswa hanya diberikan teori-teori dan cara menyelesaikan soal-soal fisika tanpa mengarahkan siswa untuk membawa konsep fisika dalam kehidupan sehari-hari. Hal tersebut menyebabkan siswa menjadi tidak aktif dan kreatif sehingga pelajaran fisika menjadi membosankan dan menjadi salah satu pelajaran yang sulit dipelajari dan tidak disukai oleh siswa.

Berdasarkan hasil studi pendahuluan yang dilakukan peneliti di SMA Negeri 9 Medan pada tanggal 15 Januari 2014, yakni wawancara dengan Guru Fisika Bapak Sitorus yang mengungkapkan bahwa hasil belajar fisika siswa masih rendah,dimana hasil belajar fisika siswa kelas XI dalam Ujian Akhir Semester Genap pada T.A.2009/2010 rata-rata 55, pada T.A. 2010/2011 rata-rata 50, pada T.A.2011/2012 rata-rata 56, dan pada T.A 2012/2013 rata-rata 55 (Daftar Kumpulan Nilai Siswa),sedangkan Kriteria Ketuntasan Minimal (KKM) yang akan dicapai adalah 70. Sehingga dapat dikatakan nilai rata-rata siswa tidak mencapai kriteria yang diharapkan. Kemudian pada tanggal 25 Januari 2014 peneliti melakukan observasi dengan memberi angket kepada siswa di SMA Negeri 9 Medan. Berdasarkan instrumen angket yang disebarkan kepada 40 orang siswa, diperoleh bahwa $42,5 \%$ siswa menyatakan bahwa fisika sulit dan kurang menarik, $25 \%$ siswa menyatakan bahwa fisika di kelas itu biasa saja, $12,5 \%$ siswa menyatakan fisika mudah dan menyenangkan, dan $20 \%$ siswa menyatakan fisika membosankan.

Berdasarkan hasil observasi di kelas XI IPA2 sewaktu guru mengajar, proses pembelajaran yang terjadi masih konvensional dan berpusat pada guru dan siswa hanya pasif dan kurang ada respon berupa pertanyaan maupun argumen ataupun minta penjelasan 
ulang. Siswa lebih sering hanya diberikan rumus-rumus yang siap pakai tanpa memahami makna dari rumus-rumus tersebut. Siswa sudah terbiasa menjawab pertanyaan dengan prosedur rutin, sehingga ketika diberikan masalah maka siswa akan kebingungan.

Berdasarkan uraian di atas, jelaslah bahwa model atau metode mengajar mempengaruhi suasana dan hasil belajar siswa.

Salah satu alternatif model pembelajaran yang memungkinkan dikembangkannya keterampilan berpikir siswa (penalaran, komunikasi, dan koneksi) dalam memecahkan masalah adalah Pembelajaran Berdasarkan Masalah. "PBM merupakan inovasi dalam pembelajaran karena dalam PBM kemampuan berpikir siswa betul-betul dioptimalisasikan melalui proses kerja kelompok atau tim yang sistematis, sehingga siswa dapat memberdayakan, mengasah, menguji, dan mengembangkan kemampuan berpikirnya secara berkesinambungan"

(Rusman,2010:229)

Berdasarkan hasil penelitian Kennedy (2008) di SMAN 4 Kisaran pada materi pokok pemuaian diperoleh nilai pretest kelas eksperimen adalah 30,666 dan ratarata kelas kontrol adalah 31,000. Kemudian setelah melakukan perlakuan yang berbeda yaitu pembelajaran berdasarkan masalah pada kelas eksperimen dan pembelajaran konvensional pada kelas kontrol, diperoleh rata-rata nilai postes pada kelas eksperimen adalah 68,666 dan rata-rata nilai kelas kontrol adalah 49,833. Dan menurut hasil penelitian Lusiana Siagian (2009) di SMPN 2 Rantau Utara pada materi pokok Listrik
Dinamis diperoleh nilai pretes kelas eksperimen adalah 4,197 dan nilai rata-rata kelas kontrol adalah 4,132. Kemudian setelah melakukan perlakuan yang berbeda yaitu pembelajaran berdasarkan masalah pada kelas eksperimen dan pembelajaran konvensional pada kelas kontrol, diperoleh hasil postes kelas eksperimen 7,54 dan nilai rata-rata kelas kontrol 6,12. Dari kedua penelitian tersebut dapat dilihat bahwa ada pengaruh yang signifikan ketika siswa diajarkan dengan menggunakan model pembelajaran Problem base Learning terhadap hasil belajar siswa.

Setyorini,dkk (2011) dalam penelitiannya menemukan bahwa "hasil kemampuan berpikir kritis siswa mengalami peningkatan secara signifikan antara kelas eksperimen yang menggunakan model PBL dan kelas kontrol yang menerapkan model DI dengan metode ceramah.Hal ini dikarenakan model Pembelajaran PBL mengajak siswa secara langsung aktif terlibat dalam proses pembelajaran."

Dari uraian yang dikemukakan di atas,maka peneliti tertarik untuk melakukan penelitian dengan tujuan untuk mengetahui pengaruh model pembelajaran Problem Based Learning untuk meningkatkan hasil belajar siswa pada materi pokok Fluida Statis di kelas XI SMA Negeri 9 Medan T.A. 2013/2014.

\section{METODE PENELITIAN}

Penelitian ini dilaksanakan di SMA Negeri 9 Medan pada semester genap T.A. 2013/2014. Waktu penelitian dilaksanakan pada bulan April - Mei 2014. Sampel dalam 
penelitian ini terdiri dari dua kelas yang dipilih secara acak dengan teknik cluster random sampling, dimana Satu kelas sebagai kelas eksperimen (kelas yang menerapkan Model Pembelajaran Problem Based Learning) yakni kelas XI-IPA1 dan satu kelas lagi sebagai kelas kontrol (kelas yang menerapkan pembelajaran konvensional) yakni kelas XI-IPA3.

Jenis penelitian ini adalah kuasi eksperimen ini dengan desain two group pretest-postest design seperti yang ditunjukkan pada Tabel 1 .

Tabel 1. Desain Penelitian tipe Two Group Pretest-Postest

\begin{tabular}{lccc}
\hline \multicolumn{1}{c}{ Kelas } & Pretes & $\begin{array}{c}\text { Perlaku } \\
\text { an }\end{array}$ & Postes \\
\hline Eksperimen & $\mathrm{T}_{1}$ & $\mathrm{X}_{1}$ & $\mathrm{~T}_{2}$ \\
\hline Kontrol & $\mathrm{T}_{1}$ & $\mathrm{X}_{2}$ & $\mathrm{~T}_{2}$ \\
\hline \multicolumn{4}{c}{ (Arikunto, 2006:85) }
\end{tabular}

Keterangan :

$\mathrm{X}_{1}$ Pembelajaran dengan

$=$ menggunakan model pembelajaran Problem

Based Learning pada materi pokok Fluida statis.

$\mathrm{X}_{2}=$ Pembelajaran dengan menggunakan pembelajaran

konvensional pada materi pokok Fluida statis.

$\mathrm{T}_{1}=$ Pretes diberikan pada kelas eksperimen dan kelas kontrol sebelum perlakuan. Tes yang diberikan berupa tes hasil belajar pada materi pokok Fluida statis.

$\mathrm{T}_{2}=$ Postes diberikan setelah perlakuan pada kelas eksperimen dan kelas kontrol.
Tes yang digunakan untuk memperoleh data hasil belajar siswa terdiri dari 2 bagian, yaitu: tes untuk pretes (kemampuan awal) dan tes untuk postes (hasil belajar) yang diberikan kepada siswa. Adapun tes yang diberikan berupa tes pilihan berganda sebanyak 16 soal, masing-masing soal mempunyai 5 option. Tes ini disusun berdasarkan analisis kurikulum KTSP, buku pegangan guru dan siswa. Sebelum tes digunakan terlebih dahulu dilakukan validitas isi oleh tiga orang validator yaitu dua orang dosen fisika Unimed, yakni Drs. Rappel Situmorang, M.Si dan Drs. Ratelit Tarigan, M.Pd serta seorang guru fisika, yakni bapak R.Sarumpaet,S.Pd,M,Si.

Berdasarkan validitas isi oleh para validator tersebut, diperoleh sebanyak 16 soal valid.

Observasi dimaksudkan untuk mengamati keseluruhan aktivitas belajar siswa selama pelaksanaan proses pembelajaran.

Teknik yang digunakan untuk menganalisis hasil belajar siswa pada penelitian ini adalah :

1. Menghitung Mean dan Standar Deviasi

2. Uji Normalitas

3. Uji Homogenitas

4. Uji Hipotesis

Data aktivitas siswa selama pembelajaran diamati oleh observer dan dianalisis dengan menggunakan skor. Presentase setiap kategori dihitung dengan menggunakan rumus sebagai berikut:

Persentase $=\frac{\text { skor yang diperoleh }}{\text { skor maksimum }} \mathrm{X} 100 \%$ 
Kriteria Penilaian :

80-100 $=$ Sangat Aktif

60-79 = Aktif

40-59 = Cukup aktif

$<40=$ Kurang aktif

\section{HASIL PENELITIAN DAN PEMBAHASAN}

\section{Hasil Penelitian}

Setelah dilakukan pretes, pada kelas eksperimen diperoleh rata-rata 42,97. Demikian halnya dengan kelas kontrol setelah pretes diperoleh rata-rata 42,15 . Untuk melihat secara rinci hasil pretes kedua kelas dapat dilihat pada Gambar 1.

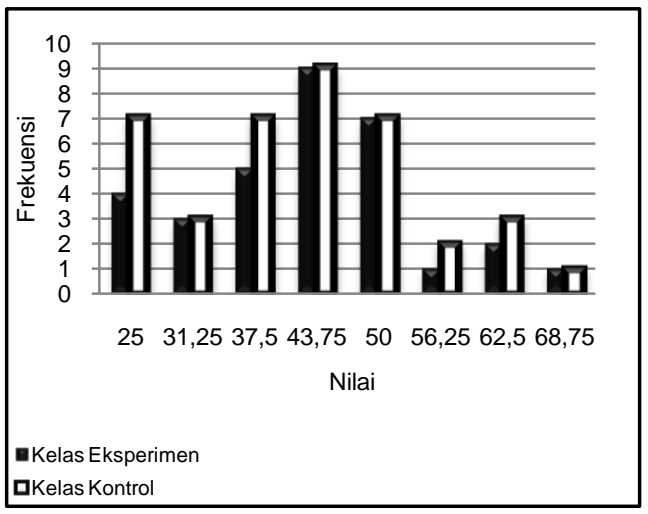

Gambar 1.Diagram Batang data pretes kelas eksperimen dan kelas kontrol

Setelah dilakukan pengajaran, kedua kelas sampel yaitu kelas eksperimen dan kelas kontrol diberikan postes yang bertujuan untuk melihat kemampuan akhir belajar siswa pada kedua kelas tersebut.

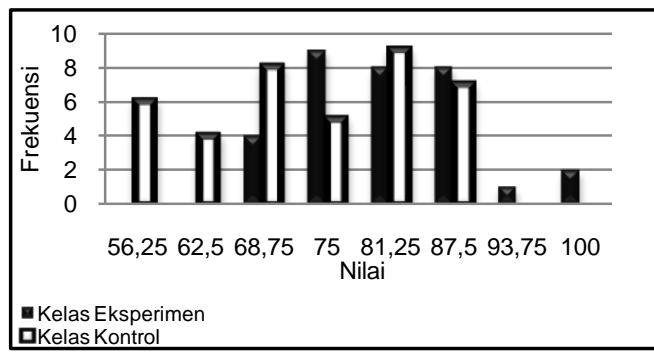

Gambar 2. Diagram Batang data postes kelas eksperimen dan kelas kontrol
Setelah dilakukan postes, pada kelas eksperimen diperoleh rata-rata 81,06. Demikian halnya pada kelas kontrol, diperoleh ratarata 73,24 . Untuk melihat secara rinci hasil pretes kedua kelas dapat dilihat pada Gambar 2.

Berikut ini ditampilkan perbandingan kemampuan kognitif siswa berdasarkan taksonomi bloom yang memiliki beberapa tingkat kemampuan.

Tabel2.Kemampuan kognitif siswa pada pretes

\begin{tabular}{|c|c|c|c|c|}
\hline \multirow{2}{*}{ Kelas } & \multicolumn{4}{|c|}{ Skor rata-rata siswa } \\
\cline { 2 - 5 } & $\mathrm{C}_{3}$ & $\mathrm{C}_{4}$ & $\mathrm{C}_{5}$ & $\mathrm{C}_{6}$ \\
\hline Eksperimen & 12,33 & 14,2 & 16,4 & 10 \\
\hline Kontrol & 12,67 & 16,20 & 20,40 & 14 \\
\hline
\end{tabular}

Data di atas dapat ditampilkan dalam bentuk diagram seperti di bawah ini.

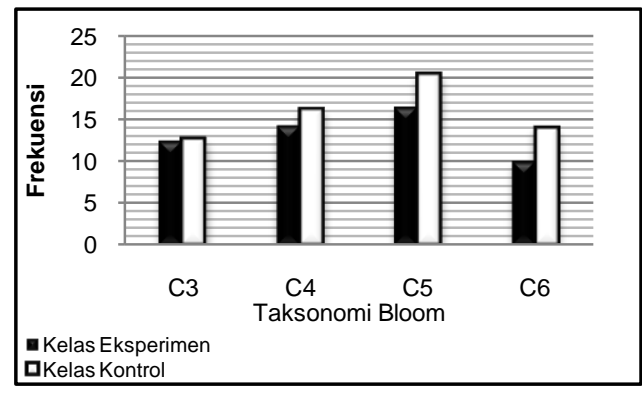

Gambar 3. Diagram batang kemampuan kognitif siswa pada pretes

Berdasarkan Gambar 3, ratarata skor kognitif siswa pada $\mathrm{C}_{5}$ (Evaluasi) adalah kemampuan yang paling banyak diperoleh siswa.

Tabel 3.kemampuan kognitif siswa pada postes

\begin{tabular}{|l|l|l|l|l|}
\hline \multirow{2}{*}{ Kelas } & \multicolumn{4}{|c|}{ Skor rata-rata siswa } \\
\cline { 2 - 5 } & $\mathrm{C}_{3}$ & $\mathrm{C}_{4}$ & $\mathrm{C}_{5}$ & $\mathrm{C}_{6}$ \\
\hline Eksperimen & 26 & 26,6 & 26,4 & 24 \\
\hline Kontrol & 28 & 28,4 & 31 & 25,33 \\
\hline
\end{tabular}


Data di atas dapat ditampilkan dalam bentuk diagram seperti di bawah ini.

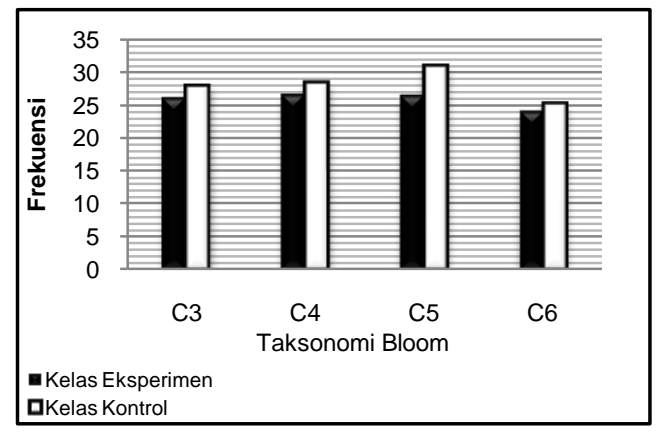

Gambar 4. Diagram batang kemampuan kognitif siswa pada postes

Berdasarkan gambar 4 terdapat perbedaan hasil belajar siswa akibat pengaruh model pembelajaran problem based learning (kelas eksperimen) dengan pembelajaran Konvensional (kelas kontrol), hal ini menunjukkan bahwa penerapan model pembelajaran problem based learningbaik untuk diterapkan.

Uji normalitas data pretes dan postes kelas eksperimen dan kelas kontrol digunakan untuk mengetahui apakah data pretes dan postes berdustribusi normal. Uji Normalitas dilakukan dengan menggunakan uji Liliefors.

Hasil uji normalitas data pretes dan postes kedua kelas dinyatakan dalam Tabel 4.

Tabel 4. Hasil Uji Normalitas Kelas Eksperimen dan Kelas Kontrol

\begin{tabular}{|l|c|c|c|c|}
\hline \multirow{2}{*}{$\begin{array}{l}\text { Kelom } \\
\text { pok }\end{array}$} & \multicolumn{2}{|c|}{ Data Pretes } & \multicolumn{2}{c|}{ Data Postes } \\
\cline { 2 - 5 } & Lhitung & Ltabel & Lhitung & Ltabel \\
\hline $\begin{array}{l}\text { Ekspe } \\
\text { rimen }\end{array}$ & 0,1393 & 0,1566 & 0,1482 & 0,1566 \\
\hline $\begin{array}{l}\text { Kontr } \\
\text { ol }\end{array}$ & 0,1150 & 0,1419 & 0,1243 & 0,1419 \\
\hline
\end{tabular}

Berdasarkan Tabel 4, untuk kelas eksperimen diperoleh nilai pretes dengan harga $L_{o}=0,1393$ dan untuk nilai postes diperoleh harga $L_{o}=0,1482$. Pada taraf signifikan $\alpha=0,05$ dan $\mathrm{n}=32$ diperoleh harga $L_{\text {tabel }}=0,1566$ maka $L_{\text {tabel }}>L_{\text {hitung }}$. Sedangkan pada kelas kontrol diperoleh nilai pretes dengan harga $L_{o}=0,1150$ dan untuk nilai postes diperoleh harga $L_{o}=$ 0,1243. Pada taraf signifikan $\alpha=$ 0,05 dan $\mathrm{n}=39$ diperoleh harga $L_{\text {tabel }}$ $=0,1419$ maka $L_{\text {tabel }}>L_{\text {hitung }}$. Dengan demikian, dapat disimpulkan bahwa data dari kedua sampel berasal dari populasi yang berdistribusi normal.

Uji homogenitas pretes dan postes kelas eksperimen dan kelas kontrol menggunakan uji kesamaan dua varians. Untuk selengkapnya perhitungan uji homogenitas tersebut tertera pada Tabel 5 .

Tabel 5. Uji Homogenitas Data Kedua Kelompok Sampel

\begin{tabular}{|c|l|c|c|c|}
\hline No & \multicolumn{1}{|c|}{ Data } & Varians & $\begin{array}{c}\mathrm{F}_{\text {hitun }} \\
\mathrm{g}\end{array}$ & $\mathrm{F}_{\text {tabel }}$ \\
\hline \multirow{8}{*}{1} & $\begin{array}{l}\text { Pretes } \\
\text { kelas } \\
\text { eskperim }\end{array}$ & & & \\
& $\begin{array}{l}\text { en } \\
\text { en }\end{array}$ & 11,89 & 1,15 & 1,76 \\
& $\begin{array}{l}\text { Pretes } \\
\text { kelas } \\
\text { kontrol }\end{array}$ & & & \\
\hline \multirow{8}{*}{2} & $\begin{array}{l}\text { Postes } \\
\text { kelas } \\
\text { eksperim } \\
\text { en }\end{array}$ & & & \\
& Postes & 10,72 & 1,66 & 1,76 \\
& kelas \\
kontrol & & & \\
\hline
\end{tabular}

Berdasarkan Tabel 5, untuk data nilai pretes diperoleh harga $F_{\text {hitung }}=1,15$. Pada taraf nyata $\alpha=$ 0,05 diperoleh harga $F_{\text {tabel }}=1,76$ maka $F_{\text {tabel }}>F_{\text {hitung. }}$ Sedangkan untuk nilai postes diperoleh harga $F_{\text {hitung }}=1,66$. Pada taraf signifikan $\alpha=0,05$ diperoleh harga 
$F_{\text {tabel }}=1,76$ maka $F_{\text {tabe }}>F_{\text {hitung. }}$. Dengan demikian, dapat disimpulkan bahwa data penelitian tersebut berdistribusi normal dan homogen, maka telah memenuhi persyaratan untuk dilakukan pengujian hipotesis.

Ringkasan perhitungan uji hipotesis untuk kemampuan pretes kelas eksperimen dan kelas kontrol ditunjukkan pada Tabel 6 .

Tabel 6. Uji Hipotesis Data Pretes

\begin{tabular}{|c|l|c|c|c|}
\hline No & Data kelas & $\begin{array}{c}\text { Nilai } \\
\text { Rata }\end{array}$ & $\begin{array}{c}\mathrm{t}_{\text {hitu }} \\
\mathrm{ng}\end{array}$ & $\begin{array}{c}\mathrm{t}_{\text {tabe }} \\
1\end{array}$ \\
\hline 1 & Eksperimen & 42,97 & 0,3 & 1,9 \\
\cline { 1 - 3 } 2 & Kontrol & 42,15 & 0 & 9 \\
\hline
\end{tabular}

Berdasarkan Tabel 6, perhitungan uji kesamaan nilai rata-rata pretes kelas eksperimen dan kelas kontrol untuk $a=0,05$, $t_{\text {hitung }}<t_{\text {tabel }}$ yaitu $0,30<1,99$, sehingga dapat disimpulkan bahwa kemampuan awal siswa pada kelas eksperimen sama dengan kemampuan awal siswa pada kelas kontrol.

Untuk pengujian hipotesis kemampuan postes dilakukan dengan uji $t$ satu pihak dengan tujuan untuk mengetahui perbedaan hasil belajar siswa yang diajar dengan model pembelajaran Problem based Learning dan yang diajar dengan pembelajaran konvensional pada materi pokok Fluida Statis dikelas XI semester genap SMA Negeri 9 Medan T.A. 2013/2014.

Secara ringkas hasil perhitungan ujihipotesis tertera pada Tabel 7.
Tabel 7. Ringkasan perhitungan uji $\mathrm{t}$

\begin{tabular}{|c|l|c|c|c|}
\hline No & \multicolumn{1}{|c|}{ Sampel } & Rata & $\begin{array}{c}\mathrm{t} \\
\text { hitung }\end{array}$ & $\begin{array}{c}\mathrm{t} \\
\text { tabel }\end{array}$ \\
\hline 1 & K. Eksperimen & 81,06 & 3,35 & 1,66 \\
2 & K. Kontrol & 73,24 & & \\
\hline
\end{tabular}

Berdasarkan $\quad$ Tabel 7 diperoleh bahwa thitung $>t_{\text {tabel }}$ yaitu 3,35>1,66maka $\mathrm{H}_{0}$ ditolak dan $\mathrm{Ha}$ diterima. Hal ini dapat disimpulkan bahwa ada perbedaan hasil belajar siswa akibat pengaruh model pembelajaran Problem Based Learning dengan pembelajaran Konvensional pada materi pokok Fluida Statis di kelas XI semester genap SMA Negeri 9 Medan T.A. 2013/2014.

Observasi dilakukan selama kegiatan belajar mengajar yang terdiri dari tiga kali pertemuan. Perkembangan aktivitas siswa di kelas eksperimen mengalami peningkatan selama menerima pembelajaran dengan model pembelajaran Problem Based Learning. Pada pertemuan I diperoleh rata-rata aktivitas siswa 36.63, pada pertemuan II diperoleh rata-rata aktivitas 57.12 , dan pada pertemuan III diperoleh rata-rata aktivitas 63.02, peningkatan aktivitas belajar siswa dari pertemuan I sampai pertemuan III dengan rata-rata nilai seluruhnya adalah 52.26 dengan kriteria penilaian aktif.

\section{Pembahasan Hasil Penelitian}

Hasil penelitian menunjukkan bahwa ada pengaruh menggunakan model pembelajaran Problem Based Learning untuk meningkatkan hasil belajar fisika siswa pada materi pokok Fluida Statis di Kelas XISemester Genap SMA Negeri 9 Medan. Hal ini diperkuat dengan perolehan nilai rata-rata pretes 
siswa di kelas eksperimen sebesar 42,97 dengan standar deviasi 11,08 dan nilai rata-rata postes sebesar 81,06 dengan standar deviasi 8,32. Sedangkan di kelas kontrol diperoleh nilai rata-rata pretes siswa sebesar 42,15 dengan standar deviasi 11,89 dan nilai rata-rata postes sebesar 73,24 dengan standar deviasi 10,72 , dan diperoleh $t_{\text {hitung }}>$ $t_{\text {tabel }}=(3,35>1,66)$ maka dapat disimpulkan bahwa $\mathrm{H}_{0}$ ditolak dan $\mathrm{H}_{\mathrm{a}}$ diterima. Berdasarkan Uji NGain, Rata-ratapeningkatan hasil belajar kelas eksperimen adalah $g=0,67$ (kategori sedang) dimana secara individu 3,12\% gain rendah, $62,5 \%$ gain sedang, dan gain tinggi $34,38 \%$. Rata-rata peningkatan hasil belajar kelas kontrol adalah $g=0,54$ (kategori sedang) dimana secara individu $12,82 \%$ gain rendah, 76,92 \% gain sedang dan gain tinggi 10,26\%.

Berdasarkan data nilai pretest dan postest beserta nilai aktivitas belajar siswa pada kelas eksperimen diperoleh bahwa siswa yang memiliki kriteria pretes sangat kurang, kriteria aktivitas kurang aktif dan kriteria postes cukup baik (SKKAC) berjumlah 1 siswa $(3,125 \%)$; siswa yang memiliki kriteria pretes sangat kurang, kriteria aktivitas kurang aktif dan kriteria postes baik (SKKAB) berjumlah 5 siswa $(15,62 \%)$; siswa yang memiliki kriteria pretes sangat kurang, kriteria aktivitas kurang aktif dan kriteria postes sangat baik (SKKAS) berjumlah 1 siswa $(3,12 \%)$; dan siswa yang memiliki kriteria pretes sangat kurang, kriteria aktivitas cukup aktif dan kriteria postes cukup baik (SKCAC) berjumlah 1 siswa (3,12\%); siswa yang memiliki kriteria pretes sangat kurang, kriteria aktivitas cukup aktif dan kriteria postes baik (SKCAB) berjumlah 8 siswa (25\%); siswa yang memiliki kriteria pretes sangat kurang, kriteria aktivitas cukup aktif dan kriteria postes sangat baik (SKCASB) berjumlah 4 siswa (12,5\%); siswa yang memiliki kriteria pretes sangat kurang, kriteria aktivitas aktif dan kriteria postes cukup (SKAC) berjumlah 2 siswa $(6,25 \%)$; siswa yang memiliki kriteria pretes sangat kurang, kriteria aktivitas aktif dan kriteria postes Baik (SKAB) berjumlah 4 siswa $(12,5 \%)$; kriteria pretes sangat kurang, kriteria aktivitas aktif dan kriteria postes sangat baik (SKASB) berjumlah 4 siswa $(12,5 \%)$; dan siswa yang memiliki pretes sangat kurang,aktivitas sangat aktif dan kriteria postes sangat baik (SKSASB) berjumlah 2 siswa $(6,25 \%)$.

\section{KESIMPULAN}

Setelah dilakukan tabulasi, perhitungan dan pengujian hipotesis diperoleh beberapa kesimpulan antara lain: (1) Hasil belajar siswa pada materi pokok Fluida Statis dengan menggunakan model pembelajaran Problem Based Learning di kelas XI SMA Negeri 9 Medan Semester Genap T.A. 2013/2014 memiliki rata-rata 81,06 dengan kategori baik. (2) Hasil belajar siswa pada materi pokok Fluida Statis dengan menggunakan pembelajaran konvensional di kelas XI SMA Negeri 9 Medan Semester Genap T.A. 2013/2014 memiliki rata-rata 73,24 dengan kategori baik. (3) Ada perbedaan hasil belajar siswa akibat pengaruh model pembelajaran Problem Based Learning dengan pembelajaran Konvensional pada materi pokok Fluida Statisdi kelas XI SMA Negeri 
9 Medan Semester Genap T.A. 2013/2014, dengan $t_{\text {hitung }}=3,35>$ $t_{\text {tabel }}=1,66$. (4) Aktivitas belajar siswa pada materi pokok Fluida Statis dengan menggunakan model pembelajaran Problem Based Learning di kelas XI SMA Negeri 9 Medan Semester Genap T.A. 2013/2014 memiliki rata-rata 52,26 dengan kategori Cukup aktif.

\section{SARAN}

Berdasarkan hasil dan kesimpulan dalam penelitian ini, maka peneliti mempunyai beberapa saran: (1) Bagi mahasiswa calon guru hendaknya lebih memahami model pembelajaran berdasarkan masalah sebagai salah satu upaya untuk mengaktifkan siswa belajar, menambah kreativitas dan semangat belajar siswa, serta meningkatkan hasil belajar siswa. (2) Kepada peneliti selanjutnya yang ingin meneliti tentang model pembelajaran berdasarkan masalah lebih lanjut, disarankan untuk lebih memperhatikan efisiensi waktu pada tahap "mengembangkan dan menyajikan hasil karya", karena pada tahap ini hampir semua siswa ingin menampilkan hasil diskusi mereka. (3) Ditinjau dari aktivitas pembelajaran,belum ada siswa yang maksimal mencerminkan akvitas model pembelajaran Problem Based Learning. Bagi peneliti atau guru selanjutnya supaya hendaknya memperbaiki redaksi indikator yang ada dalam sintaks yang belum maksimal yaitu Menunjukkan masalah, Merumuskan hipotesis, Mengidentifikasi masalah, Menganalisis masalah, Memecahkan masalah, dan Mempresentasikan hasil karya.
DAFTAR PUSTAKA

Arends, R.I., (2008), Learning To Teach, Penerbit Pustaka Belajar, Yogyakarta.

Arikunto.S, (2003), Prosedur Penelitian Suatu Pendekatan Praktik, Penerbit Rineka Cipta, Jakarta.

Arikunto, S., (2006), Prosedur Penelitian Suatu Pendekatan Praktik, Penerbit Bumi Aksara, Jakarta.

Djamarah, Z., (2006), Strategi Belajar Mengajar, Penerbit Rineka Cipta, Jakarta.

Fakultas Matematika dan Ilmu Pengetahuan Alam Universitas Negeri Medan, (2010), Buku Pedoman Penulisan Skripsi dan Proposal Penelitian Kependidikan, FMIPA Unimed, Medan.

Lestari,N.N.,(2011),Pengaruh Model Pembelajaran Berbasis Masalah (Problem Based Learning) Dan Motivasi Belajar Terhadap Prestasi Belajar fisiska Bagi siswa Kelas VII SMP. Jurnal Ilmiah Pendidikan dan Pengajaran program Pasca Sarjana UNDIKSHA: 1-21

Rusman, (2010), Model-Model Pembelajaran, Penerbit Rajagrafindo Persada, Jakarta.

Sagala, S., (2009), Konsep dan Makna Pembelajaran, Penerbit Alfabeta, Bandung.

Sanjaya,W.,(2008), Strategi Pembelajaran Berorientasi Standar Proses Pendidikan, Penerbit Kencana, Jakarta.

Sardiman.,(2009), Interaksi dan Motivasi Belajar Mengajar, Penerbit Rajawali Pers, Jakarta. 
Sardiman,(2011), Interaksi dan Motivasi Belajar Mengajar. Jakarta : PT Raja Grafindo Persada.

Setyoroni, S., Sukiswo, S.E., dan Subali, B., (2011), Penerapan Model Problem Based Learning untuk Meningkatkan Kemampuan Berpikir Kritis Siswa SMP, Jurnal Pendidikan Fisika Indonesia 7, 52-56, Jurusan Fisika FMIPA Unnes.

Sitanggang, N. 2012. Pengaruh Model Pembelajaran Berbasis Masalah Terhadap Hasil Belajar Siswa pada Materi Kesetimbangan Benda Tegar Kelas XI MAN 1 Medan T.P 2011/2012. Skripsi. Medan: FMIPA Unimed.

Slameto, (2010), Belajar dan Faktorfaktor yang

Mempengaruhinya, Rineka Cipta, Jakarta.

Sudjana,(2005), Metode Statistika, Penerbit Tarsito, Bandung.

Sudjana, (2009), Penilaian Hasil Proses Belajar Mengajar, Remaja Rosdakarya, Bandung.

Sudjana,N.,(2009), Penilaian Hasil Proses Belajar Mengajar, Penerbit Rosdakarya, Bandung.

Syah,M.,(2008), Pendidikan

Psikologi dengan

Pendekatan Baru. Bandung: Remaja Rosdakarya.

Trianto,(2007), Model-Model Pembelajaran Inovatif berorientasi

Konstruktivistik,Penerbit

Prestasi Pustaka, Jakarta.

Trianto, (2010), Mendesain Model Pembelajaran Inovatif Progresif, Penerbit Kencana, Jakarta. (http://kampus.okezone.com/read/20 13/06/01/373/816065/astaga ri-peringkat-ke-64-untukpendidikan,diakses 24 Juni 2013 11:31/) 